\title{
Sialic Acid-Binding Ig-Like Lectin 15
}

National Cancer Institute

\section{Source}

National Cancer Institute. Sialic Acid-Binding Ig-Like Lectin 15. NCI Thesaurus. Code C158386.

Sialic acid-binding Ig-like lectin 15 (328 aa, $36 \mathrm{kDa}$ ) is encoded by the human SIGLEC15 gene. This protein plays a role in both sialylated glycan binding and innate immunity. 